\title{
A dual host approach to transmembrane transport of salts
}

\author{
Stephen J. Moore, ${ }^{a}$ Matthew G. Fisher, ${ }^{a}$ and Masafumi Yano, ${ }^{a, b}$ Christine C. Tong ${ }^{a, \S}$ and Philip A. Gale ${ }^{a, *}$ \\ Received (in $X X X, X X X) X$ th $X X X X X X X X X 200 X$, Accepted $X$ th $X X X X X X X X X 200 X$ \\ First published on the web $X t h X X X X X X X X X 200 X$ \\ s DOI: 10.1039/b000000x
}

\begin{abstract}
A dual host approach for $\mathrm{M}^{+} / \mathrm{Cl}^{-}$co-transport has been shown to be effective in lipid bilayers consisting of POPC using fluorescence-based transport assays.
\end{abstract}

Ion pair complexation has attracted much attention recently 10 both in the development of receptors that can complex both components of a salt and also compounds that can transport salts across lipid bilayer membranes. ${ }^{1}$ This latter application is driven by the need to find future approaches to the treatment of diseases such as cystic fibrosis that are caused by 15 the misregulation of chloride transport across epithelial cell membranes. ${ }^{2}$ Cross talk occurs between different cation and anion transport processes in epithelial cell membranes ${ }^{3}$ and there are a number of examples of coupled cation anion transport in biological membranes. ${ }^{4}$ Gokel and co-workers has 20 previously shown that valinomycin, a naturally occurring cyclic depsipeptide which has been shown to transport potassium cations across cell membranes, can be used with synthetic chloride channels to effect release of salts from liposomes $^{5}$ and similar effects have been observed with 25 biological chloride channels. ${ }^{6}$ The combination of separate anion and cation receptors in the extraction of metal salts from aqueous to organic solution as proven to be a successful strategy. ${ }^{7}$ We wished to explore whether the same approach could be used to co-transport metal salts across lipid bilayers 30 by carriers. This is shown schematically in Scheme 1 and is achieved via two synergistically coupled uniport processes in which a cation transporter $\mathbf{C}$ and an anion transporter $\mathbf{A}$ each transport an ion resulting in effective co-transport of a salt.

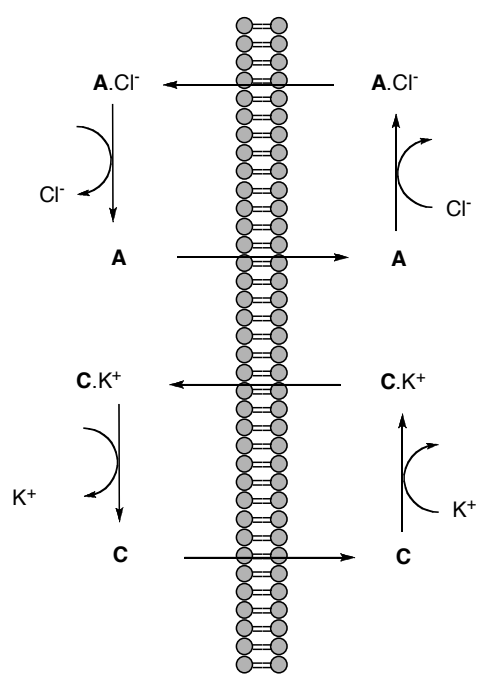

Scheme $1 \mathrm{~A}$ dual host approach to the co-transport of $\mathrm{KCl}$ by cation transporter $\mathbf{C}$ and anion transporter $\mathbf{A}$.
To achieve this we examined the chloride transport properties of calix[4]pyrroles 1-3 in the absence and presence of 40 valinomycin $4 .^{8} \mathrm{~K}^{+} / \mathrm{H}^{+}$exchange by valinomycin and protonophores such as chlorophenols have previously been shown to be coupled processes. ${ }^{9}$
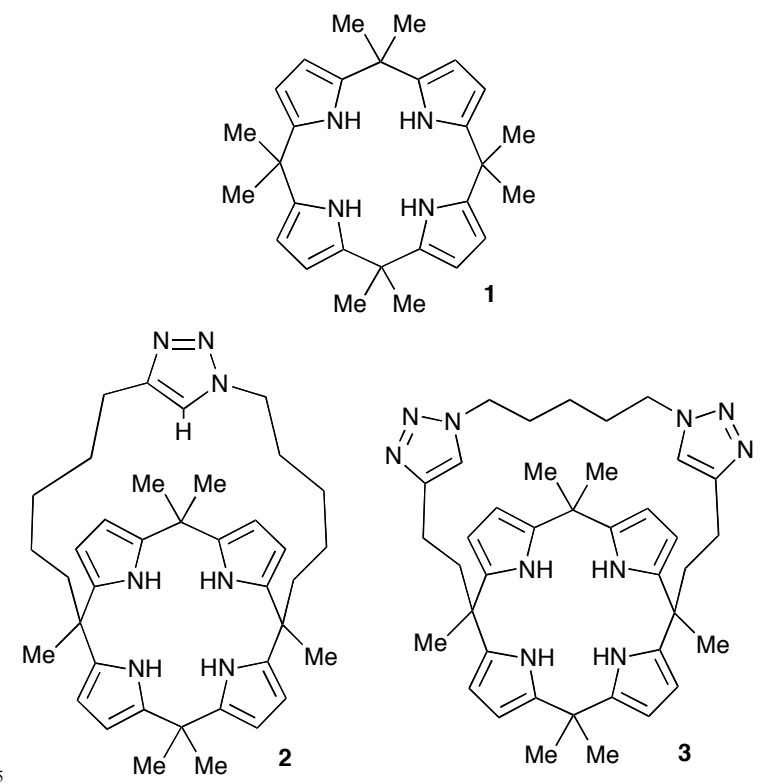

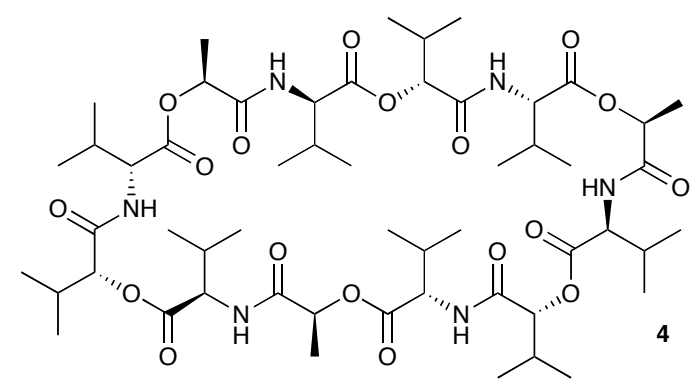

so meso-Octamethylcalix[4]pyrrole $\mathbf{1}$ has been shown to transport chloride across lipid bilayers only as part of a caesium chloride ion-pair ${ }^{10}$ whilst triazole-strapped calix[4]pyrroles $\mathbf{2}$ and $\mathbf{3}$ additionally transport chloride via an antiport process with nitrate, in which cations are not ${ }_{55}$ involved. ${ }^{11}$ So whilst compounds $\mathbf{2}$ and $\mathbf{3}$ and valinomycin could co-transport metal salts such as $\mathrm{KCl}$ via the mechanism shown in Scheme 1, this should not be possible for compound 1 and valinomycin. 
POPC vesicles were prepared in $71 \mathrm{mM}$ sodium sulfate solution buffered to $\mathrm{pH} 7.2$ with sodium phosphate and containing $1 \mathrm{mM}$ lucigenin (a chloride sensitive fluorescent dye). The vesicles were passed through a Sephadex G-50 5 column to remove unencapsulated dye and then diluted with a solution containing $5 \mathrm{mM}$ sodium phosphate and $71 \mathrm{mM}$ sodium sulfate solution to form a stock solution of vesicles containing encapsulated lucigenin.

A pulse of $\mathrm{KCl}$ (such that the concentration of added metal 10 salt in the extravesicular solution was $100 \mathrm{mM}$ ) was added and the solution allowed to equilibrate for $30 \mathrm{~s}$. The carriers were then added in acetone to give $2 \%$ molar carrier to lipid concentration. Chloride influx was monitored by following fluorescence changes of the encapsulated lucigenin (see ESI).

15 The results for addition of potasium chloride are shown in Figures $1-3$ for compounds $\mathbf{1}-\mathbf{3}$ respectively. In each case the results show the effect of adding calixpyrrole and valinomycin alone on the internal chloride concentration of the vesicles and the effect of adding valinomycin and 20 calixpyrrole together. Additionally the 'sum' of the change in concentration of chloride by adding valinomycin and calixpyrrole separately is shown. This illustrates in the case of compounds 2 and $\mathbf{3}$ the significant synergistic effect on chloride transport of adding the cationophore and anionophore

25 together (there is a significant difference between the sum of the individual concentration changes for adding the valinomycin and calixpyrrole separately $v s$. the concentration change when calixpyrroles $\mathbf{2}$ or $\mathbf{3}$ are added together with valinomycin.

30

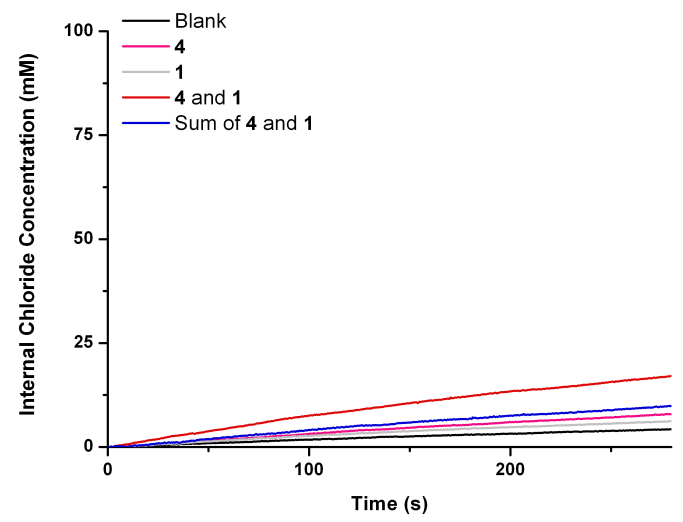

Figure 1 Change in internal chloride concentration of unilamellar POPC vesicles containing $1 \mathrm{mM}$ lucigenin, $71 \mathrm{mM}$ sodium sulfate, buffered to $\mathrm{pH}$ 7.2 with $5 \mathrm{mM}$ sodium phosphate salts and suspended in $71 \mathrm{mM}$ sodium 35 sulfate, buffered to $\mathrm{pH} 7.2$ with $5 \mathrm{mM}$ sodium phosphate salts, upon addition of an acetone solution of $\mathbf{4}(2 \mathrm{~mol} \%), \mathbf{1}(2 \mathrm{~mol} \%)$ and both $\mathbf{4}$ and $\mathbf{1}$

( $2 \mathrm{~mol} \%$ each) following a $\mathrm{KCl}$ pulse bringing the extravesicular $\mathrm{KCl}$ concentration to $100 \mathrm{mM}$.

As meso-octamethylcalixpyrrole predominantly transports 40 chloride via an ion-pair transport process with $\mathrm{CsCl}$ then only a relatively small increase in the internal chloride concentration was observed when compound $\mathbf{1}$ and valinomycin were added together (Figure 1).

In the case of compounds $\mathbf{2}$ and $\mathbf{3}$, the internal 45 concentration of chloride increases significantly more quickly when the valinomycin and triazole strapped calixpyrroles are added together, evidence supporting a co-transport process occurring as shown in Scheme 1. Upon addition of compound 2 alone there is an increase in the internal chloride so concentration. Chloride transport by this compound under similar conditions has been observed previously. ${ }^{8}$ However the enhancement in the rate of chloride transport when valinomycin and calixpyrrole $\mathbf{2}$ are added together is still significant in this case (Figure 2). Addition of calixpyrrole 3 55 and valinomycin together gives a very clear enhancement in chloride transport rate over addition of the individual component (Figure 3). Experiments conducted with $\mathrm{NaCl}$ and $\mathrm{RbCl}$ show similar results (see ESI).

It should be noted that in previous work, Smith and co60 workers had shown that salt transport could be achieved using an isophthalamide-based receptor containing a crown ether strapped across the anion binding site. ${ }^{12}$ In that case when a simple isophthalamide and a benzyl-functionalised diazozcrown ether, which represented the individual binding ${ }_{65}$ sites in the ion pair receptor, were added together no transport occurred.

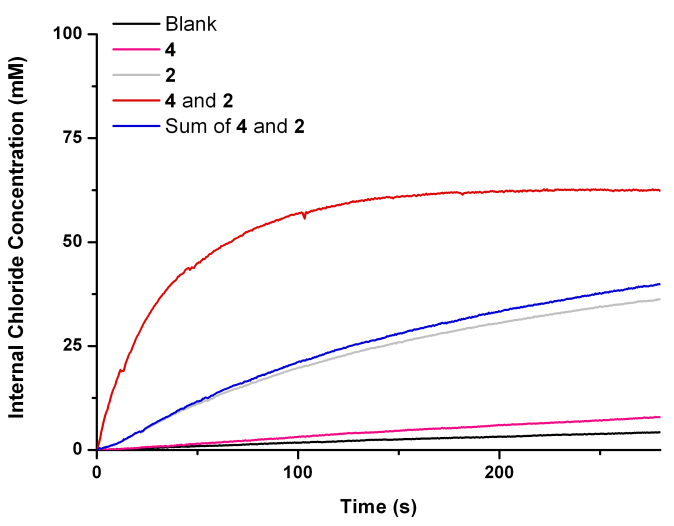

Figure 2 Change in internal chloride concentration of unilamellar POPC 70 vesicles containing $1 \mathrm{mM}$ lucigenin, $71 \mathrm{mM}$ sodium sulfate, buffered to $\mathrm{pH}$

7.2 with $5 \mathrm{mM}$ sodium phosphate salts and suspended in $71 \mathrm{mM}$ sodium sulfate, buffered to $\mathrm{pH} 7.2$ with $5 \mathrm{mM}$ sodium phosphate salts, upon addition of an acetone solution of $4(2 \mathrm{~mol} \%), 2(2 \mathrm{~mol} \%)$ and both $\mathbf{4}$ and 2 ( $2 \mathrm{~mol} \%$ each) following a $\mathrm{KCl}$ pulse bringing the extravesicular $\mathrm{KCl}$ concentration to $100 \mathrm{mM}$.

\section{Conclusions}

We have shown that addition of both a cationophore and anionophore together can result in a signficnatly enhanced 80 rate of anion transport through a lipid bilayer membrane. By separating the components of a co-tranport process (or in the future an antiport process) it may be possible to design receptors to optimise the transport of each ion transported and hence enhance transport rates and selectivity. These studies 85 are currently underway in our laboratory. 


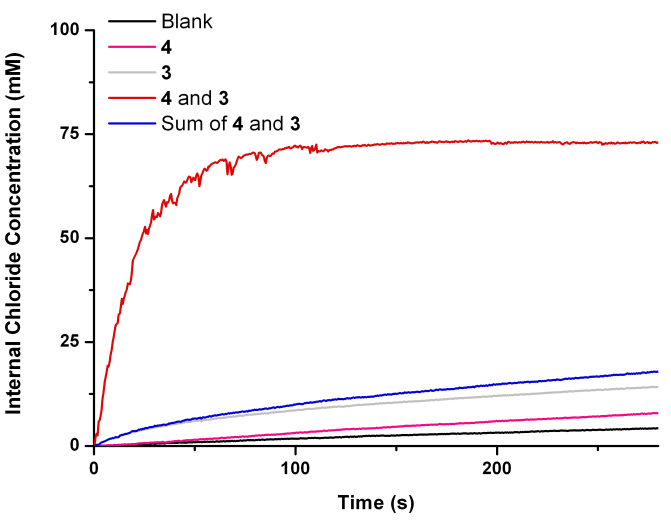

Figure 3 Change in internal chloride concentration of unilamellar POPC vesicles containing $1 \mathrm{mM}$ lucigenin, $71 \mathrm{mM}$ sodium sulfate, buffered to $\mathrm{pH}$

7.2 with $5 \mathrm{mM}$ sodium phosphate salts and suspended in $71 \mathrm{mM}$ sodium

sulfate, buffered to $\mathrm{pH} 7.2$ with $5 \mathrm{mM}$ sodium phosphate salts, upon addition of an acetone solution of 4 (2mol\%), 3 (2mol\%) and both 4 and 3

( $2 \mathrm{~mol} \%$ each) following a $\mathrm{KCl}$ pulse bringing the extravesicular $\mathrm{KCl}$ concentration to $100 \mathrm{mM}$.

\section{Acknowledgements}

PAG thanks the EPSRC and the NSF for funding. MY thanks the Kansai University's Overseas Research Program (2009) for support.

\section{Notes and references}

$15{ }^{a}$ School of Chemistry, University of Southampton, Southampton, SO17 1BJ, UK.E-mail: philip.gale@soton.ac.uk; Fax: +44 (0)23 8059 6805; Tel: + 44 (0)2380593332

${ }^{b}$ Faculty of Chemistry, Material and Bioengineering, Kansai University 3-3-35 Yamate-cho, Suita 564-8680, Japan

$20{ }^{\S}$ Present address: Department of Chemistry, Regis University, 3333 Regis Blvd, Denver, Colorado, USA 80221-1099

$\dagger$ Electronic Supplementary Information (ESI) available: details of the membrane transport studies and graphs showing change in internal chloride concentrations for analogous experiments conducted with $\mathrm{NaCl}$ 25 and $\mathrm{RbCl}$. See DOI: 10.1039/b000000x/

1 (a) For a leading review on ion-pair complexation see: S. K. Kim and J.L. Sessler, Chem. Soc. Rev. 2010, 39, 3784-3809; See also: (b) S. Roelens, A. Vacca and C. Venturi, Chem. Eur. J. 2009, 15, 2635-

2644; (c) S. Roelens, A. Vacca, O. Francesconi and C. Venturi, Chem. Eur. J. 2009, 15, 8296-8302. For recent overviews of anion complexation see: (d) P.A. Gale, Chem. Commun. 2011, DOI: 10.1039/c0cc00656d; (e) P.A. Gale, Chem. Soc. Rev. 2010, 39, 37463771 .

352 For key reviews see: J.T. Davis, O. Okunola and R. Quesada, Chem Soc. Rev. 2010, 39, 3843-3862; P.R. Brotherhood and A.P. Davis, Chem. Soc. Rev. 2010, 39, 3633-3647; A.P. Davis, D.N. Sheppard and B.D. Smith. Chem. Soc. Rev. 2007, 36, 348-357. See also: A.V. Koulov, T.N. Lambert, R. Shukla, M. Jain, J.M. Boon, B.D. Smith, H.Y. Li, D.N. Sheppard, J.B. Joos, J.P. Clare and A.P. Davis, Angew. Chem. Int., Ed., 2003, 42, 4931-4933; P. A. Gale, M. E. Light, B. McNally, K. Navakhun, K. E. Sliwinski and B. D. Smith, Chem Commun., 2005, 3773-3775; J. L. Sessler, L. R. Eller, W. S. Cho, S. Nicolaou, A. Aguilar, J. T. Lee, V. M. Lynch and D. J. Magda, Angew. Chem., Int. Ed., 2005, 44, 5989-5992; P. A. Gale, J. Garric, M. E. Light, B. A. McNally and B. D. Smith, Chem. Commun., 2007 1736-1738; R. I. Sáez Díaz, J. Regourd, P. V. Santacroce, J. T. Davis, D. L. Jakeman and A. Thompson, Chem. Commun., 2007, 2701-2703; P.V. Santacroce, J. T. Davis, M.E. Light, P. A. Gale, J.

50 C. Iglesias-Sánchez, P. Prados and R. Quesada, J. Am. Chem. Soc.,
2007, 129, 1886-1887; A. Perez-Velasco, V. Gorteau and S. Matile, Angew. Chem. Int. Ed., 2008, 47, 921-923; J.T. Davis, P.A. Gale, O.A. Okunola, P. Prados, J.C. Iglesias-Sanchez, T. Torroba and R. Quesada, Nature Chem. 2009, 1, 138-144; A. Hennig, L. Fischer, G.

55 Guichard and S. Matile, J. Am. Chem. Soc., 2009, 131, 16889-16895; C. R. Yamnitz, S. Negin, I. A. Carasel, R. K. Winter and G. W. Gokel, Chem. Commun., 2010, 46, 2838-2840; L. W. Judd and A. P. Davis, Chem. Commun. 2010, 46, 2227-2229; R.E. Dawson, A. Hennig, D.P. Welmann, D. Emery, V. Ravikumar, J. Montenegro, T. Matile, Nature Chem. 2010, 2, 533-538; N. Busschaert, P.A. Gale, C.J.E. Haynes, M.E. Light, S.J. Moore, C.C. Tong, J.T. Davis and W.A. Harrell Jr., Chem. Commun. 2010, 46, 6252-6254; N.J. Andrews, C.J.E. Haynes, M.E. Light, S.J. Moore, C.C. Tong, J.T.

65 Davis, W.A. Harrell Jr. and P.A. Gale, Chem. Sci., DOI:10.1039/C0SC00503G.

3 M.A. Robertson and J.K. Foskett, Am. J. Physiol. 1994, 267, C146C156.

4 J. Freedman, H. Rasmussen and J.W. Dobbins, Biochem. Biophys. Res. Commun. 1980, 97, 243-247.

5 P.H. Schlesinger, R. Ferdani, J. Liu, J. Pajewska, R. Pajewska, M. Saito, H. Shabany and G.W. Gokel, J. Am. Chem. Soc. 2002, 124, 1848-1849.

6 B.M. Tulk, P.H. Schlesinger, S.A. Kapadia and J.C. Edwards, J. Biol. Chem. 2000, 275, 26986-26993.

7 K. Kavallieratos, R.A. Sachelben, G.J. Van Berkel and B.A. Moyer, Chem. Commun. 2000, 187-188; K. Kavallieratos, A. Danby, G.J. Van Berkel, R.A. Sachelben, B.A. Moyer and K. Bowman-James, Anal. Chem. 2000, 72, 5258-5264; K. Kavallieratos, J.C. Bryan, R.A. 80 Aachelben, G.J. Van Berkel, O.D. Espetia, M.A. Kelly, A. Danby, K. Bowman-James and B.A. Moyer, in Fundamentals and Applications of Anion Separations Eds. B.A. Moyer and R.P. Singh, Kluwer, New York, 2004, pp125-150.

8 P. Bhattacharyya, W. Epstein and S. Silver, Proc. Nat. Acad. Sci.

85 1971, 68, 1488-1492; J.A. Kimpel and J.B. Hanson, Plant Sci. Lett. 1978, 11, 329-335; M. Pinkerton, L.K. Steinrauf and P. Dawkins, Biochem. Biphys. Res. Commun. 1969, 35, 512-518; J.A. Hamilton, M.N. Sabesan and L.K. Steinrauf, J. Am. Chem. Soc. 1981, 103, 5880-5885; G.V. Marinetti, A. Skarin and P. Whitman, J. Membrane Biol. 1978, 40, 143-155; C. Steinem, A. Janshoff, K. von dem Bruch, K. Reihs, J. Goossens and H.-J. Galla, Bioelectrochem and Bioenergetics, 1998, 45, 17-26.

9 B.S. Prabhananda and M.H. Kombrabail, J. Phys. Chem. B. 1998, 102, 8619-8628; G. Krishnamoorthy, FEBS Lett. 1988, 232, 199-203;

95 J. Hudson, A.E.G. Cass and B.S. Prabhananda, Phys. Chem. Chem. Phys. 2002, 4, 2072-2707.

10 For reports of ion-pair complexation by calixpyrroles see: R. Custelcean, L. H. Delmau, B. A. Moyer, J. L. Sessler, W.-S. Cho, D. E. Gross, G. W. Bates, S. J. Brooks, M. E. Light, and P. A. Gale, 100 Angew. Chem. Int. Ed., 2005, 44, 2537-2542; G. W. Bates, P. A. Gale, M. E. Light, CrystEngComm., 2006, 8, 300-302; G. W. Bates, P. A. Gale, M. E. Light, Supramol. Chem., 2008, 20, 23-28; D.E. Gross, F.P. Schmidtchen, W. Antonius, P.A. Gale, V.M. Lynch and J.L. Sessler, Chem. Eur. J., 2008, 14, 7822-7827; C. Caltagirone, 105 N.L. Bill, D.E. Gross, M.E. Light, J.L. Sessler and P.A. Gale, Org. Biomol. Chem. 2010, 8, 96-99.

11 C.C. Tong, R. Quesada, J.L. Sessler and P.A. Gale, Chem. Commun. 2008, 6321-6323; M. G. Fisher, P. A. Gale, J. R. Hiscock, M. B. Hursthouse, M. E. Light, F. P. Schmidtchen and C. C. Tong, Chem. Commun. 2009, 3017-3019; M. Yano, C. C. Tong, M. E. Light, F. P. Schmidtchen and P. A. Gale, Org. Biomol. Chem., 2010, 8, 43564363.

12 A.V. Koulov, J.M. Mahoney and B.D. Smith, Org. Biomol. Chem. 2003, 1, 27-29. 